\title{
PENGARUH PERSON-ORGANIZATION FIT TERHADAP KOMITMEN KARYAWAN PADA PT. KAHALA CITRA INDONESIA
}

\author{
Kalista Sabbatho \\ Magister Manajemen Universitas Mulawarman \\ kan7lista@yahoo.co.id
}

\begin{abstract}
The objective of this research is to perceive influence variable of match between the person with the purpose of organization, match between the person with the value of organization, match between the person with organizational climate, toward employee commitment with PT. Kahala Citra Indonesia where we will know how big the contribution is given by three variable of person-organiszation fit against employee commitment.

Method of research is use statistical appliance as a mmeans of test and analysis of data utilizes regression technique and multiple correlations, measurement scale used is interval scale. Frame sample in this research is employee at PT. Kahala Citra Indonesia a year on working, there are 103 questionnaire spread out to employee at PT. Kahala Citra Indonesia. Before data been analyzed, gathered data is tested with validity and reliability test, furthermore data is analyzed with multiple linier regression analysis with econometrics test which contains multicolinierity and heteroscedasticity test.

Hypothesis handed in this research is received which means incentive and work environment benefits has influence against employee commitment with degree of significance $5 \%$. All independent variable which consists of match between the person with the purpose of organization, match between the person with the value of organization, match between the person with organizational climate, have an significant effect on dependent variable (employee commitment) which deliver match between the person with the organizational climate variable has dominant partial influence against employee commitment with standardized coefficient beta 0,399. Based on regression result, there is no multicolinierity and heteroscedasticity tendency.
\end{abstract}

Keywords: person-organiszation fit , employee commitment

\section{PENDAHULUAN}

Nilai-nilai individu dari anggota organisasi haruslah sejalan dengan nilai-nilai yang ada di perusahaan yang akan menumbuhkan budaya organisasi perusahaan yang sehat. Untuk menyelaraskan antara nilai-nilai individu dan organisasi maka perlu adanya penyesuaain antara karyawan dengan perusahaan. Penyesuaian tersebut merupakan kecocokan antara individu dengan tujuan, nilai-nilai perusahaan dan iklim perusahaan saat ini.

Perubahan situasi di perusahaan tentunnya harus bisa diterima oleh banyak pihak termasuk juga karyawan. Dari perubahan nilai, tujuan dan iklim perusahaan akan menuntut karyawan untuk dapat menyesuaikan diri dengan kondisi yang ada. Karyawan dan perusahaan harus melakukan sinkronisasi persepsi. Sebagai pekerja di suatu perusahaan, karyawan haruslah mengikuti apapun segala peraturan yang telah ditetapkan oleh perusahaan.
Setiap karyawan memang memiliki motivasi, tujuan dan permasalahan dalam bekerja. Kecocokan nilai-nilai pribadi dengan perusahaan merupakan salah satu kunci terjadinya hubungan yang harmonis antara karyawan dengan perusahaan serta menjadi motivasi bagi karyawan dan perusahaan untuk dapat nxmencapai tujuan perusahaan.

Pada kenyataannya masih ada beberapa karyawan yang belum bisa menerima berbagai nilai-nilai organisasi dalam perusahaan seperti tidak disiplin dalam waktu kerja, masih seringnya terjadi pelanggaran atas keamanan dan keselamatan kerja, pemborosan terhadap peralatan kerja dan pemakaian listrik, keinginan mendapatkan promosi jabatan tanpa disertai dengan peningkatan prestasi kerja, masih terjadi adanya penerimaan fee atau uang yang tidak syah dari berbagai pihak dan masih banyak lagi permasalahan akibat dari ketidakcocokan antara keinginan dan perilaku karyawan dan perusahaan. Dari berbagai penyimpangan tersebut tentunya 
akan berdampak kepada menurunnya komitmen karyawan terhadap organisasi.

Dengan terjadi kecocokan antara karyawan dan perusahaan diharapkan akan menciptakan komitmen karyawan yang tinggi terhadap organisasi. Karyawan dapat bekerja dengan lebih baik, semangat kerja meningkat dan rasa memiliki perusahaan yang tinggi. Selain itu juga akan tumbuh keinginan untuk loyal terhadap perusahaan dengan keinginan berkerja sampai masa pensiun di perusahaan.

Komitmen karyawan sangat diperlukan bagi perusahaan agar lebih mudah mengendalikan dan memberdayakan sumber daya manusia yang ada secara maksimal. Komitmen karyawan terhadap organisasinya merupakan salah satu modal utama bagi perusahaan untuk dapat menjamin keberlangsungan operasional perusahaan. Dengan adanya komitmen karyawan diharapkan karyawan memiliki loyalitas yang tinggi.

\section{Kajian Pustaka}

\section{Person-Organization Fit}

Person-organization fit adalah judul yang menarik perhatian baik untuyk kalangan akademisi maupun manajer di perusahaan pada tahun 1990-an. Pada intinya penelitian tentang person-organization fit memperhatikan keadaan masa lalu dan konsekuensi-konsekuensi terhadap kecocokan antara peson dengan organisasi di tempat karyawan bekerja.

Person-organization fit menekankan sejauh mana seseorang dan organisasi memiliki karakteristik yang sama dalam memenuhi kebutuhan masing-masing (Sekiguchi, 2004).

Salah satu peran penting dalam manajemen sumber daya manusia adalah menetapkan penarikan, seleksi, dan penempatan karyawan berdasarkan asas "the right man in the right place anda the right man in the right job" (Hasibuan 2012:14).

Person-organization fit dapat diamati melalui proses pasca perubahan organisasi dimana secara garis besar perubahan organisasi dapat diamati melalui tujuan organisasi, perubahan nilai-nilai yang dianut perusahaan dan iklim otganisasi. (Sjabadani , 2001)

Amy (1996) mengatakan bahwa pada intinya, kecocokan orang dengan organisasi (person-organization fit) menekankan pada usaha-usaha dan dampak-dampak antara kecocokan orang dengan organisasi tempat meraka bekerja. Orang dipandang harus mampu dinamis dalam dunia organisasi yang senantiasa berubah-ubah.

Berasal dari premis utama bahwa berbagai jenis individu yag tertaril untuk beragai jenis organisasi, kesesuaian individu organisasi menekankan pentingnya kesesuaian antara karyawan dan proses kerja dan pentingnya menciptakan identitas organisasi melalui institusionalisasi nilai-nilai yang konsisten pada budaya organisasi (Morley, 2007)

\section{Tujuan Organisasi}

Handoko (1999:76) mendefinisikan tujuan organisasi sebagai "suatu pernyataan tentang keadaan yang diinginkan dimana organisasi bermaksud untuk merealisasikan" dan sebagai "pernyataan tentang keadaan diwaktu akan datang dimana organisasi sebagai kolektifitas mencoba untuk menimbulkannya".

Tujuan organisasi merupakan pernyataan tentang keadaan atau situasi yang tidak terdapat sekarang tetapi untuk dicapai pada waktu yang akan datang melalui kegiatankegiatan organisasi. Jadi, dua unsur penting tujuan organisasi adalah: (1) Hasil-hasil akhir yang diinginkan diwaktu mendatang dengan mana (2) usaha-usaha atau kegiatan-kegiatan sekarang diarahkan. Tujuan-tujuan ini dapat berupa tujuan umum atau khusus, tujuan akhir, ataupun tujuan antara.

\section{Nilai- nilai Organisasi}

Robbins (1996:130) menjelaskan, bahwa nilai adalah keyakinan-keyakinan dasar bahwa "suatu modus perilaku atau keadaan dari eksistensi yang khas lebih disukai secara pribadi atau sosial daripada suatu modus perilaku atau keadaan akhir yang berlawanan". Nilai mengandung suatu unsur pertimbangan dalam arti nilai mengemban gagasan-gagasan seorang individu mengenai apa yang benar, baik atau diinginkan.

Nilai mempunya baik atribut isi maupun intensitas. Atribut isi mengatakan bahwa suatu modus perilaku atau keadaan akhir eksistensi adalah penting. Atribut intensitas menkhususkan seberapa pentingkah itu. Bila diperingkatkan nilai-nilai seorang individu menurut intensitasnya, diperoleh sistem nilai dari orang itu. Semuanya, setiap orang mempunyai herarki nilai yang membentuk sistem nilai dari orang itu.

Sistem ini diidentifikasikan oleh kepentingan relatif yang diberikan kepada nilai- 
nilai semacam itu seperti kebebasan, kesenangan, hormat diri, kejujuran, kepatuhan, dan kesamaan (equity).

\section{Iklim Organisasi}

Wirawan, (2007) mendefinisikan bahwa iklim organisasi sebagai koleksi dan pola lingkungan yang menentukan munculnya motivasi serta berfokuspada persepsi-persepsi yang masuk akal atau dapat dinilai, sehingga mempunyai pengaruh langsung terhadap kinerja anggota organisasi. Iklim organisasi merupakan kualitas lingkungan internal organisasi yang secara relatif terus berlangsung, dialami oleh anggota organisasi, mempengaruhi perilaku mereka dan dapat dilukiskan dalam pengertian satu set karakteristik atau sifat organisasi.

\section{Komitmen Karyawan}

Menurut Mc. Shane dan Von Glinow (2003:119), komitmen organisasi adalah keterikatan emosional karyawan pada organisasi, mengidentifikasikan diri pada organisasi, dan keterlibatan karyawan pada organisasi.

Tenaga kerja yang berkomitmen adalah keunggulan kompetitif bagi perusahaan. Keunggulan kompetitif ini dikarenakan karyawan dengan masa kerja yang semakin lama mempunyai pengetahuan yang lebih baik dan para relasi lebih menyukai untuk bekerjasama dengan karyawan yang sudah dikenalnya

Aspek yang mencakup komitmen karyawan pada organisasi sangat banyak, sehingga Allen dan Mayer (1990) menyederhanakan aspek-aspek tersebut dalam tiga dimensi, yaitu:

a. Affective commitment (komitmen afektif) Affective commitment mengacu pada keterikatan emosional, identifikasi serta keterlibatan seorang karyawan pada suatu organisasi. Komitmen afektif seseorang akan menjadi lebih kuat bila pengalamannya dalam organisasi konsisten dengan harapanharapan dan memuaskan kebutuhan dasarnya dan sebaliknya. Maksudnya bahwa komitmen dipengaruhi dan atau berkembang apabila keterlibatan dalam organisasi terbukti menjadi pengalaman yang memuaskan yaitu dapat memeberikan kesempatan untuk melakukan pekerjaan dengan memuaskan atau menghasilkan kesempatan untuk menghasilkan skill yang berharga. Greenberg dan Baron (1993) mengemukakan bahwa komitmen afektif hampir sama dengan pendekatan orientasi kesamaan tujuan individu dan organisasioanl yang mewujudkan kekuatan keinginan seseorang untuk terus bekerja bagi organisasi karena merasa sejalan dan memang berkeinginan untuk melakukannya.

b. Continuance commitment (komitmen berkelanjutan)

Continuance commitment mengacu pada komitmen yang didasarkan pada kerugian- kerugian bagi karyawan bila meninggalkan organisasi. Hal ini dapat dijelaskan bahwa continuance commitment dipengaruhi dan atau dikembangkan pada saat individu melakukan investasi, yang mana investasi tersebut akan hilang atau berkurang nilainya apabila individu beralih dari organisasinya. Komitmen ini berhubungan dengan pendekatan side-bets atau pendekatan orientasi sisi pertaruhan yang menunjukkan kuatnya tendensi kebutuhan seseorang untuk terus bekerja bagi organisasi. Pendapat tersebut diperkuat oleh Greenberg dan Baron (1993) yang mengemukakan konsep side-bets orientation, yang menekankan pada sumbangan seseorang sewaktu-waktu dapat hilang jika orang itu meninggalkan organisasi. Tindakan meninggalkan organisasi menjadi suatu yang beresiko tinggi karena orang merasa takut akan kehilangan sumbangan yang mereka tanamkan pada organisasi itu dan menyadari bahwa mereka tidak mungkin mencari penggantinya. Karyawan dengan komitmen berkelanjutan yang kuat akan tetap tinggal karena mereka merasa bahwa membutuhkan organisasi dan cenderung menghindari kerugian finansial.

c. Normative commitment (komitmen normatif)

Normative commitment merupakan jaminan yang dirasakan untuk tetap tinggal di organisasi. Komitmen normatif dipengaruhi dan atau berkembang sebagai hasil dari internalisasi tekanan normatif untuk melakukan serangkaian tindakan tertentu dan penerimaan keuntungan yang 
menimbulkan perasaan akan kewajiban yang harus dibalas. Karyawan merasa wajib untuk tetap tinggal dalam suatu organisasi karena adanya perasaan hutang budi pada organisasi sehingga mereka mempunyai kewajiban moral untuk melakukan kewajiban timbal balik pada organisasi tempat meraka bekerja. Karyawan dengan komitmen normatif yang kuat akan tetap tinggal karena mereka seharusnay melakukan hal tersebut sebagai balasan atas apa yang telah diterimanya dari organisasi.

\section{Kerangka Konsep}

Berdasarkan teori dan latar belakang permasalahan, disajikan kerangka konseptual dari penelitian sebagai berikut:

\section{Person-Organization Fit}

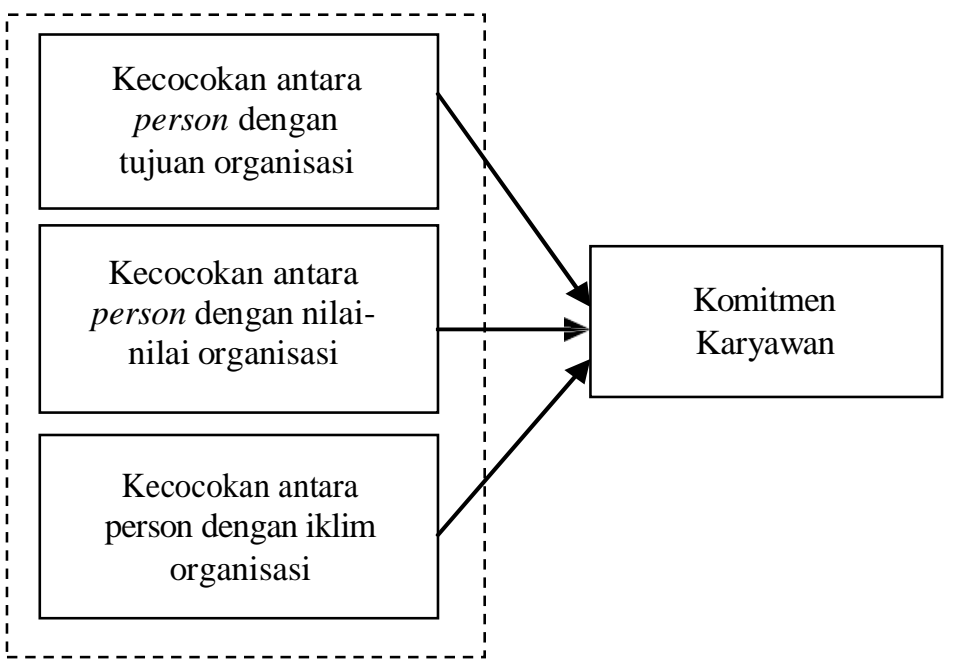

Gambar 2.1 Kerangka Konsep

\section{Hipotesis}

Berdasarkan kerangka konsep penelitian tersebut dapat di hipotesiskan sebagai berikut

a. Hipotesis pertama, terdapat pengaruh signifikan dari variabel-variabel person- organization fit yaitu kecocokan antara person dengan tujuan organisasi, kecocokan antara person dengan nilai-nilai organisasi dan kecocokan antara person dengan iklim organisasi terhadap komitmen karyawan pada PT. Kahala Citra Indonesia.

b. Hipotesis kedua, diduga variabel kecocokan antara person dengan iklim organisasi memiliki pengaruh yang dominan terhadap komitmen karyawan pada PT. Kahala Citra Indonesia.

\section{METODE PENELITIAN}

Untuk mengetahui pengaruh variabelvariabel person-organization fit terhadap komitmen karyawan, maka data-data primer yang diperoleh melalui penyebaran kuesioner dilakukan analisis secara kuantitatif dengan bantuan program SPSS 25 for windows.

Data bersumber dari 103 responden yang merupakan seluruh karyawan PT. Kahala Citra Indonesia

Hasil pengujian validitas dapat dilihat pada tabel di bawah ini :

Tabel 5.1

Hasil uji Validitas Variabel 


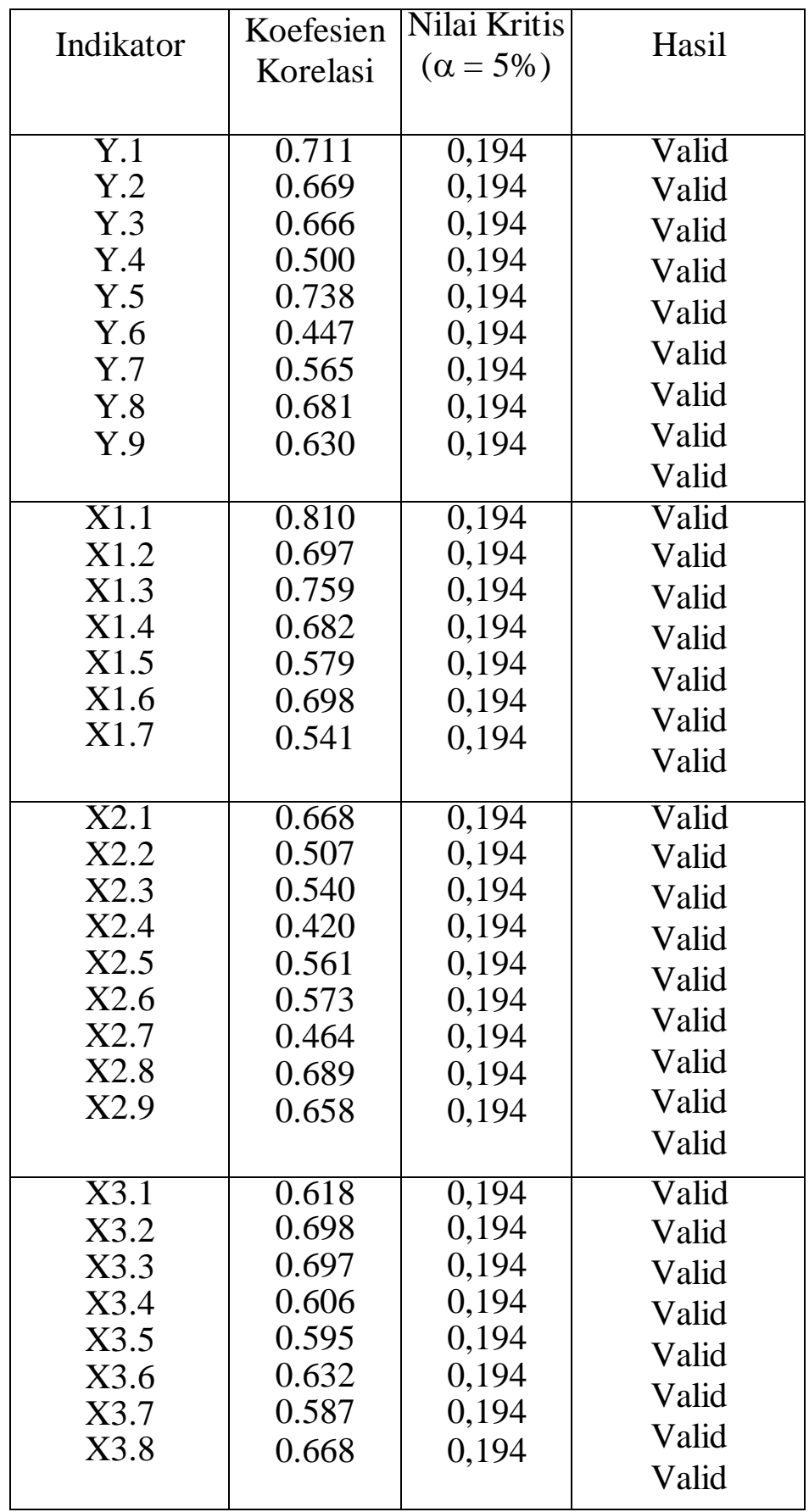

Sumber: data primer diolah

Hasil pengujian reliabilitas dapat dilihat pada tabel di bawah ini :

Tabel 5.2

Hasil Uji Reliabilitas

\begin{tabular}{|c|c|c|c|}
\hline Variabel & $\mathrm{r}$ alpha & $\mathrm{r}$ & Hasil \\
\hline Komitmen Karyawan (Y) & 0,804 & 0,600 & Reliable \\
\hline $\begin{array}{c}\text { Kecocokan antara person } \\
\text { dengan tujuan organisasi } \\
\text { (X1) }\end{array}$ & 0,803 & 0,600 & Reliable \\
\hline $\begin{array}{c}\text { Kecocokan antara person } \\
\text { dengan nilai- nilai } \\
\text { organisasi (X2) }\end{array}$ & 0,733 & 0,600 & Reliable \\
\hline $\begin{array}{c}\text { Kecocokan antara person } \\
\text { dengan iklim organisasi } \\
\text { (X3) }\end{array}$ & 0,806 & 0,600 & Reliable \\
\hline
\end{tabular}

Berdasarkan tabel 5.2, diketahui bahwa koefesien reliabilitas alat ukur dalam penelitian ini mempunyai nilai lebih besar dari 0,6 . Hal ini berarti bahwa kuesioner yang digunakan untuk mengukur semua variabel independen dan variabel dependen memiliki kehandalan yang tinggi atau hasil pengukuran dapat diterima dengan baik.

TABEL 5.3.

Coefficients $^{\mathrm{a}}$

\begin{tabular}{|c|c|c|c|c|c|}
\hline \multirow[b]{2}{*}{$\begin{array}{c}\text { Model } \\
\text { (Constant) }\end{array}$} & \multicolumn{2}{|c|}{$\begin{array}{l}\text { Unstandardized } \\
\text { Coefficients }\end{array}$} & \multirow{2}{*}{$\begin{array}{l}\text { Standardi } \\
\text { zed } \\
\text { Coefficien } \\
\text { ts } \\
\text { Beta }\end{array}$} & \multirow[b]{2}{*}{$\begin{array}{c}\mathrm{t} \\
1.694\end{array}$} & \multirow[b]{2}{*}{$\begin{array}{l}\text { Sig. } \\
.093\end{array}$} \\
\hline & $\begin{array}{c}\mathrm{B} \\
.541\end{array}$ & $\begin{array}{c}\text { Std. Error } \\
.303\end{array}$ & & & \\
\hline X1.Tujuan & .191 & .088 & .217 & 2.183 & .031 \\
\hline $\begin{array}{l}\text { Organisasi } \\
\text { X2. Nilai }\end{array}$ & .312 & .102 & .257 & 3.055 & .003 \\
\hline $\begin{array}{l}\text { Organisasi } \\
\text { X3. Iklim } \\
\text { Organisasi }\end{array}$ & .399 & .082 & .435 & 4.877 & .000 \\
\hline
\end{tabular}

Sumber: data primer diolah

Berdasarkan hasil perhitungan analisis regresi linier berganda seperti yang tertuang dalam tabel 5.3 di atas maka dapat menghasilkan persamaan regresi sebagai berikut :

$\mathrm{Y}=0,541+0,191 \mathrm{X} 1+0,312 \mathrm{X} 2+0,399 \mathrm{X} 3$

Tabel. 5.4

Model Summary

\begin{tabular}{|l|c|c|c|c|} 
Model & $\mathrm{R}$ & $\mathrm{R}$ Square & $\begin{array}{c}\text { Adjusted R } \\
\text { Square }\end{array}$ & $\begin{array}{c}\text { Std. Error of the } \\
\text { Estimate } \\
1\end{array}$ \\
\hline
\end{tabular}

Sumber: data primer diolah 
Besarnya kontribusi variabel-variabel bebas secara serentak terhadap variabel tidak bebasnya dapat dilihat dari koefisien determinasi $\left(\mathrm{R}^{2}\right)$. Tabel 5.4. menunjukkan bahwa besarnya koefisien determinasi $\left(\mathrm{R}^{2}\right)=$ $0,659(65,9 \%)$, berarti bahwa dalam model regresi linier berganda ini variabel-variabel bebasnya secara bersama-sama mampu memberikan kontribusi pada variabel tidak bebasnya sebesar 65,9\% dan sisanya sebesar $34,1 \%$ dipengaruhi oleh variabel lain yang tidak dimasukkan dalam model penelitian ini.

Besarnya koefisien korelasi (Multiple R) adalah 0,812 atau $81,2 \%$, berarti hal ini menunjukkan terjadinya hubungan positif yang cukup erat/kuat antara variabel-variabel bebas dengan variabel tidak bebasnya.

Tabel. 5.5

Model Summaryb

\begin{tabular}{|r|r|r|r|r|r|}
$\begin{array}{c}\text { R Square } \\
\text { Change }\end{array}$ & F Change & df 1 & df 2 & \multicolumn{1}{|c|}{$\begin{array}{c}\text { Sig. F } \\
\text { Change }\end{array}$} & $\begin{array}{c}\text { Durbin- } \\
\text { Watson } \\
.659\end{array}$ \\
& 63.682 & 3 & 91 & .000 & 1.865 \\
& & & & \\
\hline
\end{tabular}

Sumber: data primer diolah

Hipotesis pertama yang menyatakan bahwa pengaruh terdapat pengaruh signifikan dari variabel-variabel person-organization fit yaitu kecocokan antara person dengan tujuan organisasi, kecocokan antara person dengan nilainilai organisasi dan kecocokan antara person dengan iklim organisasi terhadap komitmen karyawan pada PT. Kahala Citra Indonesia akan dibuktikan dengan menggunakanuji serentak atau uji F. Tabel 5.5. menujukkan bahwa besarnya Fhitung $=63,682$ lebih besar dari F-tabel yaitu 2,696, dengan level of significant ( $\square$ ) sebesar $5 \%$.

Berarti hal ini menunjukkan bahwa besarnya angka probabilitas menunjukkan 0.000 $<0,05$, dengan demikian dapat disimpulkan sebagai berikut :

1) Ho yang menyatakan bahwa variabel- variabel person-organization fit yaitu kecocokan antara person dengan tujuan organisasi, kecocokan antara person dengan nilai-nilai organisasi dan kecocokan antara person dengan iklim organisasi secara bersama-sama tidak memiliki pengaruh terhadap komitmen karyawan pada PT. Kahala Citra Indonesia adalah ditolak.
2)H1 yang menyatakan bahwa variabel- variabel person-organization fit yaitu kecocokan antara person dengan tujuan organisasi, kecocokan antara person dengan nilai-nilai organisasi dan kecocokan antara person dengan iklim organisasi secara bersamasama memiliki pengaruh yang bermakna terhadap komitmen karyawan pada PT.

Kahala Citra Indonesia, adalah diterima.

Berdasarkan kesimpulan ini, maka hipotesis pertama yang menyatakan bahwa variabel- variabel person-organization fit yaitu kecocokan antara person dengan tujuan organisasi, kecocokan antara person dengan nilainilai organisasi dan kecocokan antara person dengan iklim organisasi secara bersama-sama memiliki pengaruh terhadap komitmen karyawan pada PT. Kahala Citra Indonesia terbukti kebenarannya.

Pengujian terhadap hipotesis kedua terbukti kebenarannya, karena hasil uji t seluruh variabel lebih besar dari t-tabel yaitu 1,664 dan variabel kecocokan antara person dengan iklim organisasi (X3) 4,877 merupakan nilai terbesar dibandingkan dengan hasil $\mathrm{t}$ hitung dari variabel lainnya. Jadi variabel kecocokan antara person dengan iklim organisasi memiliki pengaruh dominan terhadap komitmen karyawan pada PT. Kahala Citra Indonesia terbukti kebenarannya.

\section{PEMBAHASAN}

Koefisien determinasi parsial (r2) untuk masing-masing variabel bebas adalah sebagai berikut : kecocokan antara person dengan tujuan organisasi (X1) 12,8\%, kecocokan antara person dengan nilai- nilai organisasi (X2) $16,8 \%$, kecocokan antara person dengan nilai- nilai organisasi (X3) 28,6\%, Nilai r2 adalah untuk mengetahui sejauh mana besarnya sumbangan masing-masing variabel bebas terhadap variabel tidak bebas dan untuk mengetahui variabel bebas mana yang mempunyai sumbangan terbesar (dominan) terhadap variabel tidak bebas.

Dari 3 variabel person-organization fit tersebut kecocokan antara person dengan iklim organisasi (X3) mempunyai kontribusi terbesar terhadap komitmen karyawan pada PT. Kahala Citra Indonesia.

\section{a. Kecocokan antara person dengan tujuan organisasi (X1)}

Nilai rata-rata tanggapan responden terhadap variabel kecocokan antara person dengan tujuan organisasi 
adalah sebesar 3,89, yang menunjukan variabel kecocokan antara person dengan tujuan organisasi dari person- organization fit di PT. Kahala Citra Indonesia adalah tinggi. Tingkat variabel kecocokan antara person dengan tujuan organisasi yang tinggi dari organisasi merupakan bentuk keinginan karyawan untuk mendukung tujuan organisasi di PT. Kahala Citra Indonesia melalui peningkatan disiplin dan keselamtan kerja.

Variabel kecocokan antara person dengan tujuan organisasi berpengaruh secara positif signifikan terhadap komitmen karyawan pada PT. Kahala Citra Indonesia. Hal ini sesuai dengan teori yang dikemukakan oleh Etzioni dalam Handoko (1999:76) mendefinisikan tujuan organisasi sebagai "suatu pernyataan tentang keadaan yang diinginkan dimana organisasi bermaksud untuk merealisasikan" dan sebagai "pernyataan tentang keadaan diwaktu akan datang dimana organisasi sebagai kolektifitas mencoba untuk menimbulkannya".

Jika variabel kecocokan antara person dengan iklim organisasi naik satu satuan akan mengakibatkan meningkatnya komitmen karyawan sebesar 19,1\%. Secara parsial variabel kecocokan antara person dengan tujuan organisasi berpengaruh positif terhadap variabel terikatnya yang dapat dilihat dari hasil uji t-nya. Dari hasil estimasi t- hitung 2,183 yang lebih besar dari t-tabel yaitu 1,664 dengan probabilitas kesalahan 5\%, pengaruh kecocokan antara person dengan tujuan organisasi terhadap komitmen karyawan ditandai pula dengan konstribusi kecocokan antara person dengan tujuan organisasi terhadap komitmen karyawan sebesar $34,9 \%$ bila variabel bebas lainnya dianggap konstan.

Pengaruh kecocokan antara person dengan tujuan organisasi terhadap komitmen karyawan dapat terjadi karena karyawan merasa tujuan organisasi yang ditetapkan oleh perusahaan untuk kelangsungan perusahaan dan mempertahankan karyawannya untuk bekerja majadi satu team. Perusahaan mengharapkan setiap karyawan mematuhi segala peraturan tentang keamanan, kebersihan dan keselamatan kerja. Dengan mematuhi peraturan tersebut tujuan perusahaan menciptakan lingkungan kerja yang bersih, aman dan aman akan tercapai.

b. Kecocokan antara person dengan nilainilai organisasi (X2)

Nilai rata-rata tanggapan responden terhadap variabel kecocokan antara person dengan nilai-nilai organisasi adalah sebesar 4,12, yang menunjukkan variabel kecocokan antara person dengan nilai-nilai organisasi dari person- organization fit di PT. Kahala Citra Indonesia adalah tinggi. Tingkat variabel kecocokan antara person dengan nilai-nilai organisasi yang tinggi merupakan salah satu keinginan karyawan terhadap perusahaan di PT. Kahala Citra Indonesia melalui berbagai aktifitas penghematan biaya operasional perusahaan, bekerja dengan moralitas tinggi dan berorientasi pada peningkatan kinerja.

Variabel kecocokan antara person dengan nilai-nilai organisasi berpengaruh secara positif signifikan terhadap komitmen karyawan pada PT. Kahala Citra Indonesia. Jika variabel kecocokan antara person dengan nilai-nilai organisasi naik satu satuan akan mengakibatkan kenaikan komitmen karyawan sebesar 31,2\%.

Hal ini sesuai dengan teori yang dikemukakan Robbins (1996:130) menjelaskan, bahwa nilai adalah keyakinan-keyakinan dasar bahwa "suatu modus perilaku atau keadaan dari eksistensi yang khas lebih disukai secara pribadi atau sosial daripada suatu modus perilaku atau keadaan akhir yang berlawanan". Nilai mengandung suatu unsur pertimbangan dalam arti nilai mengemban gagasan-gagasan seorang individu mengenai apa yang benar, baik atau diinginkan.

Secara parsial variabel kecocokan antara person dengan nilai-nilai organisasi berpengaruh secara positif terhadap variabel terikatnya hal ini dapat dilihat dari uji t. Dari hasil analisis t hitung sebesar 3,055 yang lebih besar dari t-tabel yaitu 1,664 dengan probabilitas kesalahan diatas $5 \%$ yaitu 0,003 , kontribusi variabel kecocokan antara person dengan nilai-nilai organisasi terhadap komitmen karyawan 
sebesar $17,9 \%$, bila variabel bebas lainnya dianggap konstan.

Pengaruh variabel kecocokan antara person dengan nilai-nilai organisasi terhadap komitmen karyawan dikarenakan karyawan merasakan dengan melakukan penghematan penggunaan listrik, air, bahan bakar minyak untuk kendaraan operasional dan alat tulis kantor akan mengurangi biaya operasioanal perusahaan yang akan berdampak efesiensi.

Penerapan bekerja yang beretika dengan tidak menerima uang yang tidak sah dalam bentuk apapun dan dari siapapun akan meningkatkan nilai-nilai organisasi.

\section{c. Kecocokan antara person dengan iklim organisasi (X3) \\ Nilai rata-rata tanggapan} responden terhadap variabel kecocokan antara person dengan iklim organisasi adalah sebesar 4,19, yang menunjukan variabel kecocokan antara person dengan iklim organisasi dari person- organization fit di PT. Kahala Citra Indonesia adalah cukup tinggi.

Kecocokan antara person dengan iklim organisasi yang cukup tinggi dari organisasi merupakan salah satu keinginan karyawan terhadap organisasi di PT. Kahala Citra Indonesia yang merupakan suatu keinginan karyawan bekerja dengan adanya hubungan yang harmonis antara karyawan dengan pimpinan dan karyawan dengan rekan kerja yang lain.

Variabel kecocokan antara person dengan iklim organisasi berpengaruh secara positif signifikan terhadap komitmen karyawan di PT. Kahala Citra Indonesia. Jika variabel kecocokan antara person dengan iklim organisasi naik satu satuan akan mengakibatkan meningkatnya komitmen karyawan sebesar 39,9\%. Hal ini sesuai dengan teori yang dikemukakan oleh Davis dan Newstrom (1995), iklim organisasi adalah lingkungan manusia didalam mana para karyawan organisasi melakukan pekerjaan mereka. Iklim organisasi tidak dapat dilihat atau disentuh tetapi ia ada dan mempengaruhi segala hal yang terjadi dalam organisasi.

Secara parsial variabel Promosi berpengaruh secara positif tidak signifikan terhadap variabel terikatnya hal ini dapat dilihat dari hasil uji t-nya. Dari hasil estimasi t testnya sebesar 4,877 yang lebih kecil dari t-tabel yaitu 1,664 dengan probabilitas kesalahan diatas $5 \%$ yaitu 0,000 , dan konstribusi variabel iklim organisasin terhadap komitmen karyawan sebesar $28,6 \%$ bila variabel bebas lainnya dianggap konstan.

Variabel kecocokan antara person dengan iklim organisasi merupakan harapan dari karyawan yang menginginkan adanya hubungan yang harmonis antara karyawan dan pimpinan. Kepemimpinan yang ramah dan selalu memperhatikan masukan dan kritikan dari karyawan akan dapat menciptakan iklim organisasi yang nyaman untuk bekerja.

Bekerja dengan secara kelompok akan mempermudah komunikasi antar karyawan dan pimpinan yang akan berdampak terciptanya hubungan antar rekan kerja yang harmonis.

\section{KESIMPULAN}

Berdasarkan hasil analisis dan pembahasan, maka dapat disimpulkan sebagai berikut :

a. Hasil pengujian terhadap variabelvariabel yang dirumuskan dalam hipotesis ternyata mendukung teori yang telah dideskripsikan sebelumnya, bahwa hipotesis yang diajukan dalam penelitian ini dapat diterima, bahwa terdapat pengaruh signifikan dari variabel- variabel person-organization fit yaitu kecocokan antara person dengan tujuan organisasi, kecocokan antara person dengan nilai-nilai organisasi dan kecocokan antara person dengan iklim organisasi terhadap komitmen karyawan pada PT. Kahala Citra Indonesia.

b. Secara parsial variabel yang dominan berpengaruh terhadap terhadap komitmen karyawan pada PT. Kahala Citra Indonesia adalah variabel kecocokan antara person dengan iklim organisasi. Kecocokan antara person dengan iklim organisasi yang ingin menciptakan lingkungan kerja yang bersih, aman dan tingkat keselamatan kerja yang tinggi serta peningkatan kinerja dengan bekerja efektif. 


\section{Saran}

Dari hasil kesimpulan di atas, berikut ini diajukan saran:

a. Dilihat dari hasil analisis yang menunjukkan variabel kecocokan antara person dengan iklim organisasi, sekiranya perlu dilakukan sosialisasi tentang bagaimana menciptakan lingkunagan kerja yang sehat dan harmonis. Diharapkan dengan adanya sosialisasi akan berdampak positif bagi karyawan dan perusahaan pada masa sekarang dan masa yang akan datang.

b. Tindakan tegas dari pimpinan perusahaan terhadap karyawan yang melanggar tata tertib dan peraturan agar ulah beberapa oknum karyawan PT. Kahala Citra Indonesia yang melanggar tidak berdampak negatif bagi semua karyawan dan perusahaan.

c. Variabel kecocokan antara person dengan tujuan organisasi perlu diperhatikan implementasinya karena dalam penelitian ini variabel kecocokan antara person dengan tujuan organisasi merupakan yang terendah. Berarti masih ada karyawan yang belum atau selaras dengan tujuan organisasi. Tujuan Organisasi tersebut perlu lebih dibangun dengan cara memperbanyak sosialisasi tentang perusahaan secara komprehensif.

\section{DAFTAR PUSTAKA}

Allen dan Mayer. (1990). The Measurement And Antecedents OfAffective, Continuance And Normative Commitment To The Organization. Journal of Occupational Psychology 63(1):1-18

Amy L. Kristof, 1996. Person-Organisation Fit: An Intergratif Review of Its Conceptualisation, Measurenment, and Implications, Personnel Psycology, 46,

Arifianingsih, Jeanita, 2017. Pengaruh Person Organization Fit Terhadap Kinerja Karyawan Melalui Kepuasan Kerja Sebagai Variabel Intervening. Skripsi Program Studi Manajemen, Universitas Islam Negeri Syarif Hidayatillah Jakarta.

Greenberg, J. \& Robert Baron, A. 1993 Behavior in Organization Understanding ang Managing The Human Side of Work. Third Edition. Penerbit. Allyn and Bacon, Nedham Heights Inc.
Guntur Mahardika (2006) .Pengaruh Person Organization Fit (Kecocokan Nilai-Nilai Individu Dengan Nilai-nilai Organisasi) Terhadap Kepuasan Kerja, Komitmen Organisasional Dan Kinerja Karyawan (Studi Pada RSI PKU Muhammadiyah Pekalongan). Tesis Magister Manajemen Program Pasca Sarjana Universitas Diponegoro, Semarang

Handoko, T. Hani. 1999. Manajemen Personalia dan Sumber Daya Manusia. BPFE-UGM, Yogyakarta.

Hasibuan, Melayu. 2012"Manajemen Sumber Daya Manusia”. Jakarta : PT Bumi Aksara. Indiantoro, Nur \& Bambang Supomo. 2002. Metodologi Penelitian Bisnis untuk Akuntansi \& Manajemen. Cetakan kedua. Yogyakarta: BPFE

Judge, TA. Ferris, GR. 1992. The exclusive criterion of fit in human resource staffing decicions. Human Resources Planning. Pp. 443-463.

Luthans, F. (1995). Organizationj Behafior, McGraw-Hill Company, Literatur, New York, Seventh Edition.

Mc. Shane dan Von Glinow,.2003, Organization Behavior. McGraw-Hill Company

Muchinsky, PM. Monahan, C.J. 1998. What is person environmentcongruence? Supplementary versus complementary models of fit. Journal of vocational behavior, Vol. 31, p.269

Morley, J. Michael. 2007, Person Organization Fit. Journal of Managerial Psycology, Vol.2 ISS:2, pp109-117

Syabadhani, B., dkk. 2001. Pengembangan Kualitas Sumber Daya Manusia dan Prespektif. Fakultas Psikologi Universitas Indonesia, Jakarta.

Sekiguchi, T. 2004. Person-Organization Fit And Person - Job Fit In Enployee Selection: A Review Of The Literature. Osaka Keidai Ronshu. Vol. 54 No. 6 pp 179- 196

Stephen P. Robbins, 1996. Perilaku Organisasi, Konsep, Kontroversi dan Aplikasi. Alih Bahasa : Hadyana Pujaatmaka. Edisi Keenam. Penerbit PT.Bhuana Ilmu Populer, Jakarta.

Wirawan, 2007, Budaya dan iklim organisasi, Salemba Empat, Jakarta. 


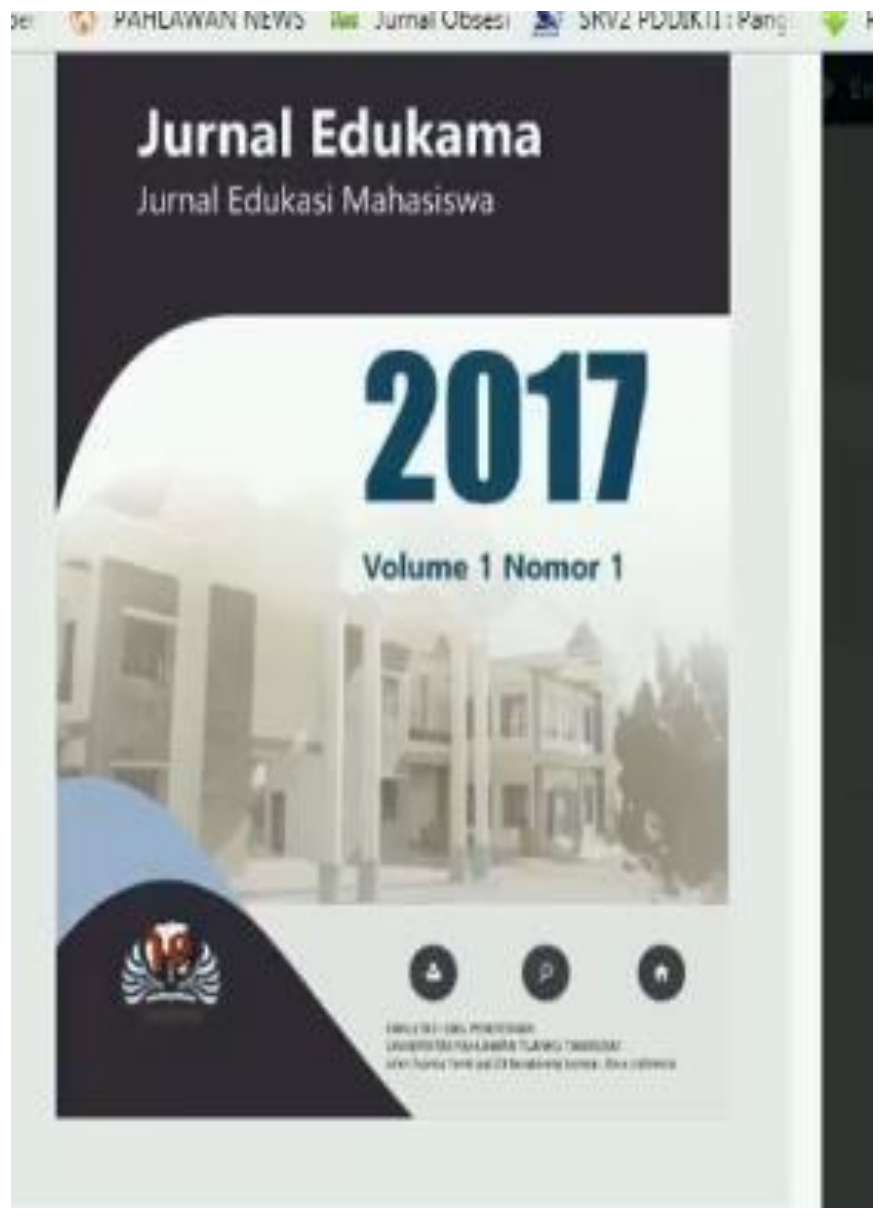

